\title{
Species of Hypholoma (Fr.) P. Kumm. (Strophariaceae, Agaricales) in Rio Grande do Sul State, Brazil ${ }^{1}$
}

\author{
Vagner Gularte Cortez ${ }^{2}$ and Rosa Mara Borges da Silveira ${ }^{3}$
}

Received: February 10, 2006. Accepted: December 12, 2006

\begin{abstract}
RESUMO - (Espécies de Hypholoma (Fr.) P. Kumm. (Strophariaceae, Agaricales) no Rio Grande do Sul, Brasil). Neste trabalho são apresentadas descrições, ilustrações, discussões e chave de identificação para as espécies do gênero Hypholoma (Fr.) P. Kumm. conhecidas no estado do Rio Grande do Sul, além de uma revisão do material de Hypholoma depositado na coleção Fungi Rickiani. A partir das coletas realizadas pelos autores, bem como estudo do material depositado nos principais herbários do estado e do país, verificou-se a ocorrência das seguintes espécies: H. aurantiacum (Cooke) Faus, H. ericaeum (Pers.: Fr.) Kühner e H. subviride (Berk. \& M.A. Curtis) Dennis.
\end{abstract}

Palavras-chave: Basidiomycota, Agaricomycetidae, Stropharioideae, Nematoloma, micobiota brasileira

\begin{abstract}
Species of Hypholoma (Fr.) P. Kumm. (Strophariaceae, Agaricales) in Rio Grande do Sul State, Brazil). Detailed descriptions, illustrations, discussions and a key for identification of the known species of the genus Hypholoma (Fr.) P. Kumm. in Rio Grande do Sul state are presented, as well as a revision of the Hypholoma specimens deposited in the Fungi Rickiani collection. Based on the authors' collections and the herbarium revision, the following species were recognized: H. aurantiacum (Cooke) Faus, H. ericaeum (Pers.: Fr.) Kühner, and H. subviride (Berk. \& M.A. Curtis) Dennis.
\end{abstract}

Key words: Basidiomycota, Agaricomycetidae, Stropharioideae, Nematoloma, Brazilian mycobiota

\section{Introduction}

The genus Hypholoma (Fr.) P. Kumm. belongs to the family Strophariaceae Singer \& A.H. Sm. (Agaricales, Basidiomycota), subfamily Stropharioideae (Singer) Singer, and is characterized by the presence of well-pigmented pileus, variably developed veil, but never forming a membranous annulus on the stipe, spore print violaceous to purplish, basidiospores with a thickened wall and a conspicuous germ-pore, and presence of chrysocystidia (Pegler 1983; Singer 1986; Smith 1951; Watling \& Gregory 1987). The absence of acanthocytes in the rhizomorphs separates it from the closest genus Stropharia (Fr.) Quél. (Farr 1980; Norvell \& Redhead 2000). The presence of chrysocystidia is a distinguishing character from Psilocybe (Fr.) P. Kumm., another related genus in the family (Guzmán 1980; 1983; 1999). According to Hawksworth et al. (1995), Hypholoma comprises about 30 species worldwide, distributed from temperate to tropical areas, growing on decomposing wood, live trees, mosses or soil (Singer 1986).

The nomenclature of the genus has been discussed over the years by different authors (Baletto 1989; Dennis et al. 1954; Farr \& Farr 1981; Singer \& Smith 1946). Several Hypholoma species were placed in the past in the genus Nematoloma P. Karst. (Singer 1986; Smith 1951), which finally suffered nomenclatural rejection (Korf 1986). Recently, species of the genus were considered by Noordeloos $(1995 ; 1999)$ as subgenera of Psilocybe s.l., based on Smith (1979) and Kühner (1980), but this proposal was not well accepted among mycologists (Bon \& Roux 2003; Norvell \& Redhead 2000) and overall it was not supported by recent molecular studies (Moncalvo et al. 2002). According to Moncalvo et al. (2002), Hypholoma is recognized as an independent clade, composed of most of its species, except $H$. subericaeum (Fr.) Kühner and $H$. aurantiacum (Cooke) Faus [as S. aurantiaca (Cooke) M. Imai],

\footnotetext{
1 Parte da Dissertação de Mestrado do primeiro Autor

2 Universidade Federal do Rio Grande do Sul, Programa de Pós-graduação em Botânica, Av. Bento Gonçalves 9500, 91501-970 Porto Alegre, RS, Brasil

3 Universidade Federal do Rio Grande do Sul Programa de Pós-graduação em Botânica, Av. Bento Gonçalves 9500, 91501-970 Porto Alegre, RS, Brazil (rosa.silveira@ufrgs.br)

4 Corresponding Author: cortezvg@yahoo.com.br
} 
which have an uncertain position in the "stropharioid" clade.

Species of Hypholoma are not edible; in fact, those belonging to the group of $H$. fasciculare (Huds.: Fr.) P. Kumm. are considered poisonous (Badalyan et al. 1995). This species has also been investigated for its antioxidant (Badalyan 2003) and hypoglycemic (Badalyan \& Serrano 1999) activities. As active wood and litter decomposers, they also play an important role in forest ecosystems, being currently used in bioconversion of cellulose, fabric and dye industrial residues (Hofrichter \& Fritsche 1997; Steffen et al. 2000), and also in biological control of phytopathogenic fungi (Badalyan et al. 2002; Chapman et al. 2004).

In Brazil, few studies reported species of Hypholoma. Singer (1973) described Nematoloma amazonicum Singer and N. nudum Singer from Northern Brazil; Pegler (1997) reported H. subviride (Berk. \& M.A. Curtis) Dennis and H. trinitensis (Dennis) Pegler in São Paulo state; Stijve \& de Meijer (1993) cited Psilocybe alnetorum (Singer) Singer, which is in fact $H$. alnetorum (Singer) Guzmán (Guzmán 1999), from the state of Paraná.

In Rio Grande do Sul, several species were reported by Rick (1907; 1930; 1939; 1961), most, however, are synonyms of species belonging to other agaric genera, especially Psilocybe (Strophariaceae) and Psathyrella (Fr.) Quél. [Psathyrellaceae (Singer) Vilgalys, Moncalvo \& Redhead]. Other important records were given by Singer (1953), who studied some of Rick's collections, and more recently Cortez \& Coelho (2004) and Sobestiansky (2005) reported the occurrence of $H$. subviride in the regions of Santa Maria and Nova Petrópolis, respectively.

In the present work we revised the known species of Hypholoma from Rio Grande do Sul state, based on the authors' collections and material deposited in regional and national herbaria, especially those of the Fungi Rickiani collection.

\section{Materials and methods}

Specimens were collected from March 2004 to September 2005, in different localities of Rio Grande do Sul state (Fig. 1). Material deposited in the following herbaria, listed according to the Index Herbariorum

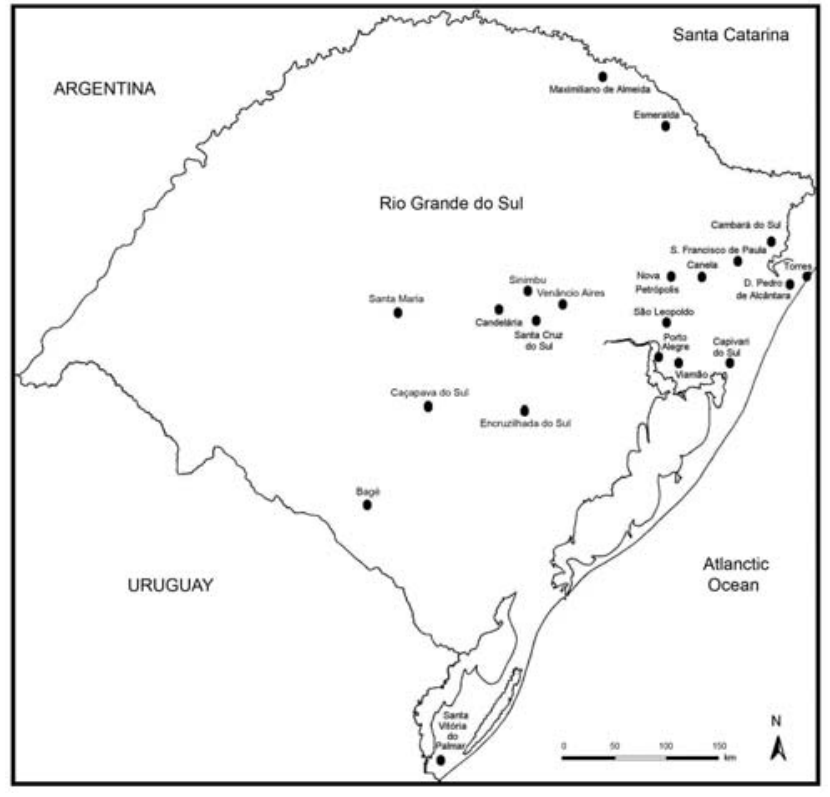

Figure 1. Map of Rio Grande do Sul (RS), showing the collecting sites of the studied taxa.

(Holmgren \& Holmgren 1998-2005), were also studied: HASU, HCB, ICN, PACA, SMDB, and SP. All collected material is deposited in the herbarium ICN.

The macroscopic analysis followed Largent (1977), while the microscopic study of the basidiomata followed Largent et al. (1986). As mounting media 5\% KOH (potassium hydroxide) alone or with $1 \%$ Congo Red were used. Line drawings were made with a camera lucida in a Leica DM LS2 optical microscope. For the basidiospore descriptions, $Q$ is the ratio of length to width, $Q_{m}$ is the medium value of $Q$, and $n$ is the number of measured basidiospores. Color terminology was taken from Munsell (1994), unless not indicated. All scientific names, independent of taxonomic rank are italicized, following Hawksworth (2001), and all taxonomic authorities are abbreviated according to the Authors of Fungal Names (CABI 2005).

\section{Results and discussion}

In this study, three species of the genus Hypholoma were recognized as occurring in Rio Grande do Sul. The following key is provided for their identification. 
Key for the known species of Hypholoma in Rio Grande do Sul state

1. Basidiomata cespitose on wood; pileus sulphur-yellow; basidiospores 6-8 $\mu \mathrm{m}$ long 3. H. subviride

1. Basidiomata not cespitose; pileus differently colored; basidiospores longer than $10 \mu \mathrm{m}$..... 2

2. Pileus yellowish brown, dry; veil absent or poorly developed; growing on wet soil, among grasses and mosses

2. Pileus dark red to red, subviscid to viscid; veil forming white scales in the pileus margin and a fibrillose annulus in the stipe; growing on fallen branches and leaves 1. H. aurantiacum

Description of the species

1. Hypholoma aurantiacum (Cooke) Faus, Bol. Soc. Micol. Castell. 7: 70, 1982. Fig. 2-8, 24.

Agaricus squamosus f. aurantiacus Cooke, Handb. Br. Fungi 2: 199, 1884.

Stropharia aurantiaca (Cooke) M. Imai, J. Agric. Hokk. Imp. Univ. 43: 267, 1938.

S. aurantiaca (Cooke) P.D. Orton, Trans Br. Mycol. Soc. 43: 181, 1960. (superfl. comb.).

Naematoloma aurantiacum (Cooke) Guzmán, Beih. Nova Hedw. 51: 114, 1975 (comb. inval.).

N. aurantiacum (Cooke) Guzmán ex Singer, Agaric. Mod. Taxon.: 564, 1986.

Psilocybe aurantiaca (Cooke) Noordel., Persoonia 16: 128, 1995.

Pileus 18-39 mm diam., convex to flattened, umbonate; color dark red (10R 3/6) in young basidiomata, becoming red (10R 4/8) with age; surface smooth, viscid to subviscid; margin regular, striate, with appendiculate white scales; context fleshy and whitish. Lamellae adnexed, close; color light brownish gray (10YR 6/2) when young, to dark yellowish brown (10YR 4/6) at maturity; margin regular, whitish. Stipe 40-87 x 3-5 mm, central, cylindrical, with a curved and expanded base; color white in young stages, becoming reddish (2.5YR 4/8) towards the base; surface dry, squamulose to fibrillose; consistency fibrous, hollow; rhizomorphs and basal mycelium very abundant, white. Veil present; in the pileus it produces whitish scales adhered to margin, which are rarely present in older basidiomata; on the stipe it produces a fibrillose annular zone, also seen only in younger basidiomata. Spore print violaceous brown. Basidiospores (9.5-)11-15(-17) $\times$ (6.5-)7-8.5 $\mu \mathrm{m},\left(Q=1.57-2.20, Q_{m}=1.78, n=85\right)$; ellipsoid in side view, to slightly ovoid in frontal view; smooth and thick-walled, with a truncate germ-pore; yellowish brown in $\mathrm{KOH}$. Basidia 22-33×9-13 $\mu$ m; clavate, hyaline, thin-walled, bearing four sterigmata. Pleurocystidia (26-)35-55×10-14(-17) $\mu \mathrm{m}$; as chrysocystidia, fusiform with rostrate apex or clavate with mucronate apex; smooth and thin-walled, hyaline, but with amorphous yellowish contents under $\mathrm{KOH}$. Cheilocystidia 23-42(-53) $\times 4-8 \mu \mathrm{m}$; as leptocystidia, cylindrical and sinuous, to sublageniform with rounded to subcapitate apex; smooth and thin-walled, hyaline, without contents; very numerous in the gill edge. Pileipellis of ixocutis type, composed by interwoven, gelatinized hyphae, with thin and non-incrusted walls, 2.5-8 $\mu$ m diam., with rounded terminal portion, clamped. Hypodermium cellular, formed by subglobose hyphae, 22-45 $\mu \mathrm{m}$ diam., with irregularly thickened, yellowish walls. Context composed of inflated hyphae, smooth and thin-walled, 6-16 $\mu \mathrm{m}$ diam. Hymenophoral trama regular, formed by parallel, inflated to filamentous hyphae, $8-18 \mu \mathrm{m}$ in diameter, with smooth and slightly thickened walls, hyaline. Stipitipellis composed of parallel, non-gelatinized, hyaline hyphae, 3-8 $\mu \mathrm{m}$ diam., smooth and thin-walled. Caulocystidia 35-71 $\times 5-13 \mu \mathrm{m}$; as leptocystidia, ventricose-rostrate to cylindrical, with subcapitate apex, similar to the cheilocystidia; smooth and thin-walled, hyaline, without yellowish contents; disposed in fascicles in the stipe apex. Clamp connections present in most septa.

Habitat: gregarious on plant debris (small branches, fallen leaves) in disturbed forests and parks.

Distribution: Africa (Reid \& Eicker 1999), Asia (Guzmán 1975), Australasia (Grgurinovic \& Simpson 2001; Segedin \& Pennycook 2001), Europe (Noordeloos 1999; Watling \& Gregory 1987), North America (Guzmán 1975), and South America (Singer 1969; Wright \& Albertó 2002).

Material examined: BRAZIL. Rio Grande do Sul: Maximiliano de Almeida, Usina Hidrelétrica de Forquilha, 9/VII/2005, M.S. Rother 072 (ICN); Porto Alegre, Parque Farroupilha, 13/V/2005, Cortez 039/05 (ICN 139.117); São Francisco de Paula, Floresta Nacional do IBAMA, 7/VI/1996, Sulzbacher et al. (HCB 16.694), Veraneio Hampel, 4/VI/2004, Cortez 028/04 (ICN 139.011); São Leopoldo, 1905, Rick 15.228 (PACA 9.378); Viamão, Parque Estadual de Itapuã, 10/IX/2005, M.S. Rother 082 (ICN), Parque 

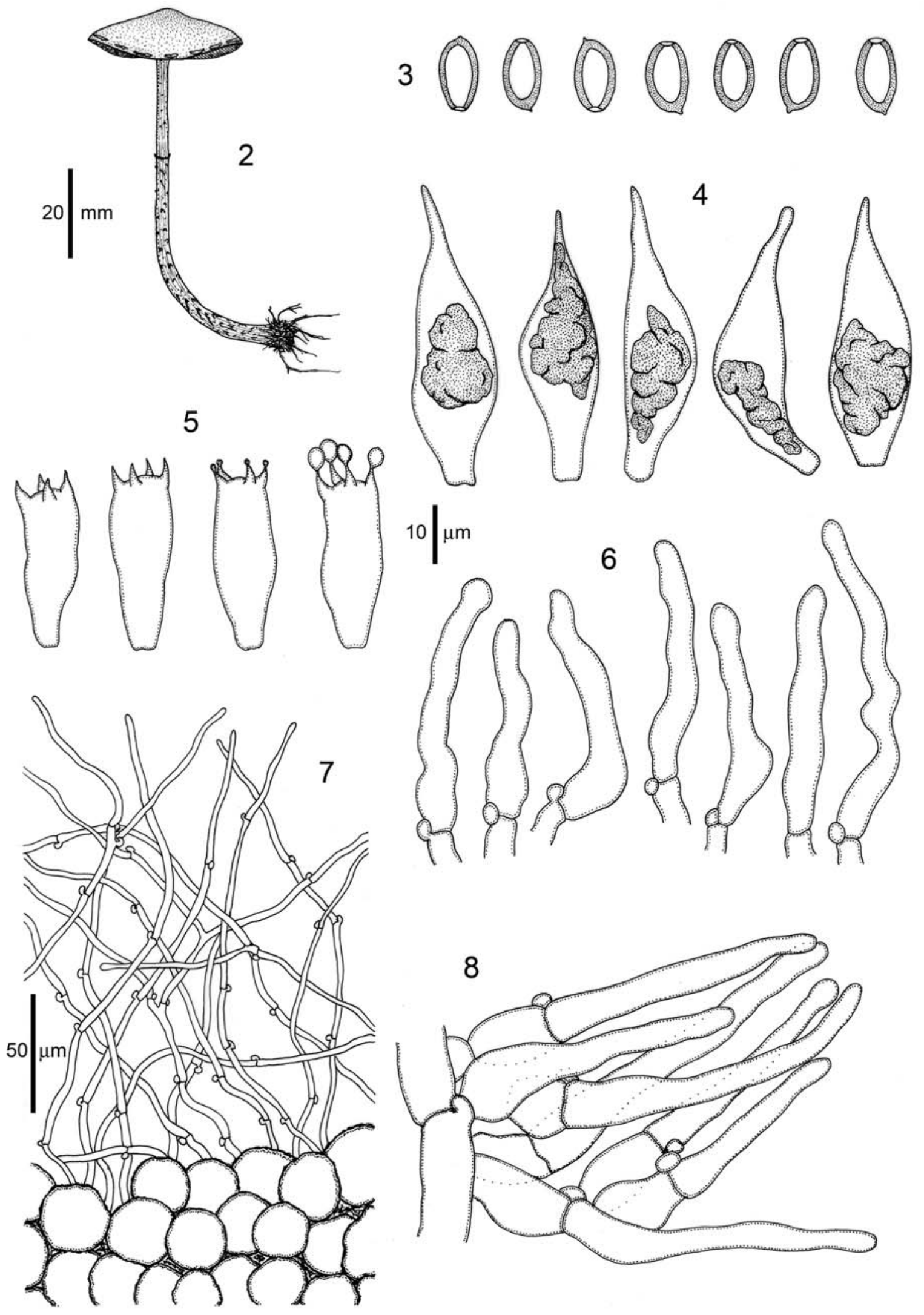

Figures 2-8. Hypholoma aurantiacum. 2. Basidioma. 3. Basidiospores. 4. Pleurocystidia. 5. Basidia. 6. Cheilocystidia. 7. Pileipellis and hypodermium. 8. Caulocystidia. 
Saint-Hilaire, V/1995, R.T. Guerrero \& R.M. Silveira (ICN 102.574), III/1996, R.T. Guerrero \& R.M. Silveira (ICN 102.550).

Discussion: This species is frequently referred to in the European literature as Stropharia aurantiaca (Cooke) M. Imai (Pegler \& Legon 1998) or S. aurantiaca (Cooke) P.D. Orton (Watling \& Gregory 1987) due to the presence of fibrillose annulus, but the absolute lack of acanthocytes in the rhizomorphs excludes it from that genus. Flammula puiggarii, described by Spegazzini (1889) has been used in SouthAmerican literature to name this mushroom (Raithelhuber 1985; Wright \& Albertó 2002; both as Hypholoma puiggarii). However, the holotype of Spegazzini is identical to Stropharia rugosoannulata Farl. ex Murrill, as previously indicated by Singer (1950) and Pegler (1997). Spegazzini's F. puiggarii (1889) is an older name than S. rugosoannulata (Murrill 1922), but the latter is a well-kwon name used for a cultivated mushroom; the proposal for the rejection of the former and conservation of the name $S$. rugosoannulata is needed. The specimens studied by Singer (1969) as Nematoloma puiggarii (Speg.) Singer, except for the type of $F$. puiggarii, possibly corresponds to $H$. aurantiacum as here presented.

The purplish color of the basidiomata and the viscid to subviscid pileus surface, as well the fibrillose annulus and the presence of abundant rhizomorphs are characteristic of this species. Scanning electronmicroscopy studies (Farr 1985) revealed the presence of a singular ornamentation of the basidiospore wall, composed of slightly rugulate and baculate elements, however under light microscope the basidiospores are smooth. Molecular systematics have pointed out that $H$. aurantiacum has close affinities with the mushroom Stropharia magnivelaris Peck and the secotioids Leratiomyces similis (Pat.) Bresinsky \& Binder and Weraroa erythrocephala (Tul. \& C. Tul.) Singer \& A.H. Sm., suggesting its exclusion from the genus Hypholoma (Moncalvo et al. 2002).

In Brazil, H. aurantiacum was first reported from Rio Grande do Sul state by Rick (1907) as Stropharia thrausta Kalchbr., which was later cited by Guzmán (1975) as Naematoloma sp.; we confirmed these specimens as $H$. aurantiacum as described above. It was also cited by Sobestiansky (2005) from the region of the Southern Plateau of Rio Grande do Sul (Nova Petrópolis) and by de Meijer (2001) from the state of Paraná, both as $S$. aurantiaca. The latter author also reported $H$. puiggarii in the same paper, but he did not discuss the differences between these two names.
Stropharia coccinea Pearson ex Pegler, an African species described by Pegler (1996), is very similar in all macro and microscopic features and should be compared, being a probable synonym of this species.

2. Hypholoma ericaeum (Pers.: Fr.) Kühner, Bull. Soc. Mycol. Fr. 52: 23, 1936. Fig. 9-15, 25.

Agaricus ericaeus Pers.: Fr., Syst. Mycol. 1: 291, 1821.

Psilocybe ericaea (Pers.: Fr.) Quél., Mém. Soc. Émul. Montbél. Sér. II, 5: 333, 1873.

Stropharia subumbonatescens Murrill, Mycologia 33: 280, 1941.

Nematoloma subumbonatescens (Murrill) Singer, Lilloa 22: 220, 1951.

N. ericaeum (Pers.: Fr.) A.H. Sm., Mycologia 43: 485, 1951.

Pileus 9-34 mm diam., campanulate, plano-convex to umbonate, with low, rounded to acute umbo; color yellowish brown (10YR 5/6-5/8) in the center to yellow (10YR 7/8) towards the margin; surface smooth, subviscid to dry, non-hygrophanous; margin curved, with few velar fibrils in younger basidiomata; context fleshy, firm, whitish to yellowish. Lamellae adnexed, close; color light brownish gray (10YR 6/2) when young, then reddish black (2.5YR 2.5/1) to black (5YR 2.5/1) at maturity; margin regular, whitish, pulverulent under a stereoscopic microscope, due to the presence of numerous cheilocystidia. Stipe 41-85(-112) $\times(1.5-)$ 2-5 mm, central, cylindrical, sometimes sinuous, with sub-bulbous base; color yellow (2.5Y 7/6) to olive yellow (2.5Y 6/6); surface longitudinally striate, dry to somewhat humid; consistency fibrous, hollow; rhizomorphs and basal mycelium poorly developed, usually absent. Veil absent to very inconspicuous, forming a vestigial annular zone on the stipe apex and leaving some remnants in the pileus margin. Spore print violaceous brown. Basidiospores 12-15(-16) ×7.5-9 $\mu \mathrm{m}$ $\left(Q=1.44-1.88, Q_{m}=1.68, n=103\right)$, ellipsoid in side view to slightly ovoid in frontal view; smooth and thickwalled, with truncate germ-pore; color yellowish brown in $\mathrm{KOH}$. Basidia 24-41×8-11 $\mu \mathrm{m}$; utriform to subclavate, with medial constriction; smooth and thinwalled; bearing four sterigmata. Pleurocystidia 30-54×9-17 $\mu \mathrm{m}$; as chrysocystidia, fusiform, with mucronate apex, sometimes rostrate; smooth and thinwalled, with amorphous yellowish contents. Cheilocystidia (22-)27-44(-52)×6-10 $\mu \mathrm{m}$, subcylindrical to lageniform, subcapitate, hyaline, smooth and thinwalled, numerous. Pileipellis of ixocutis type, comprising filamentous, interwoven, and slightly 


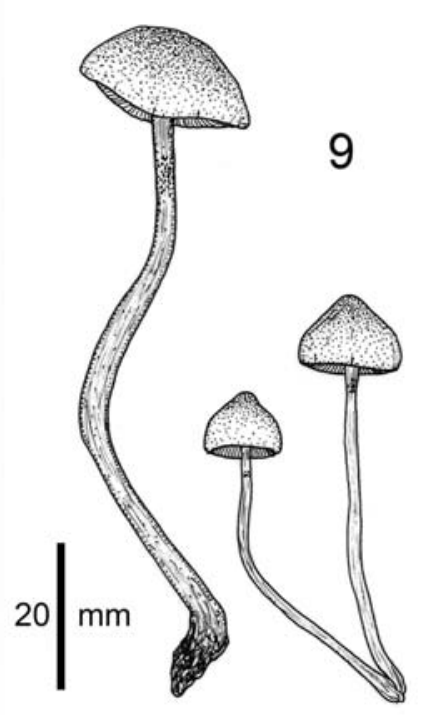

12
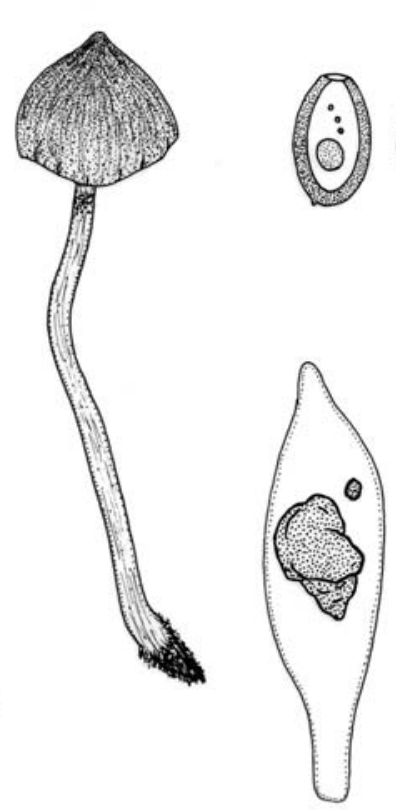
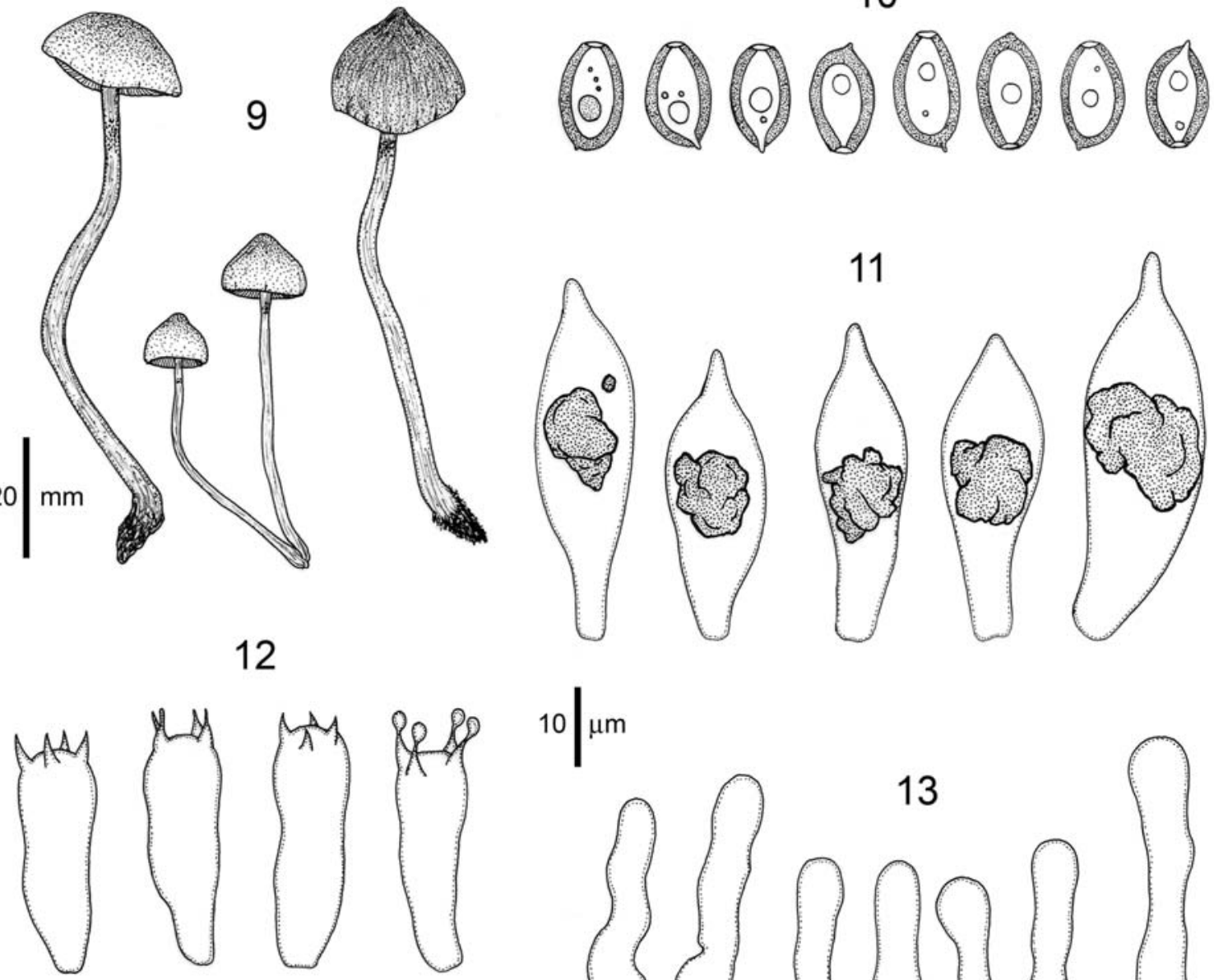

14
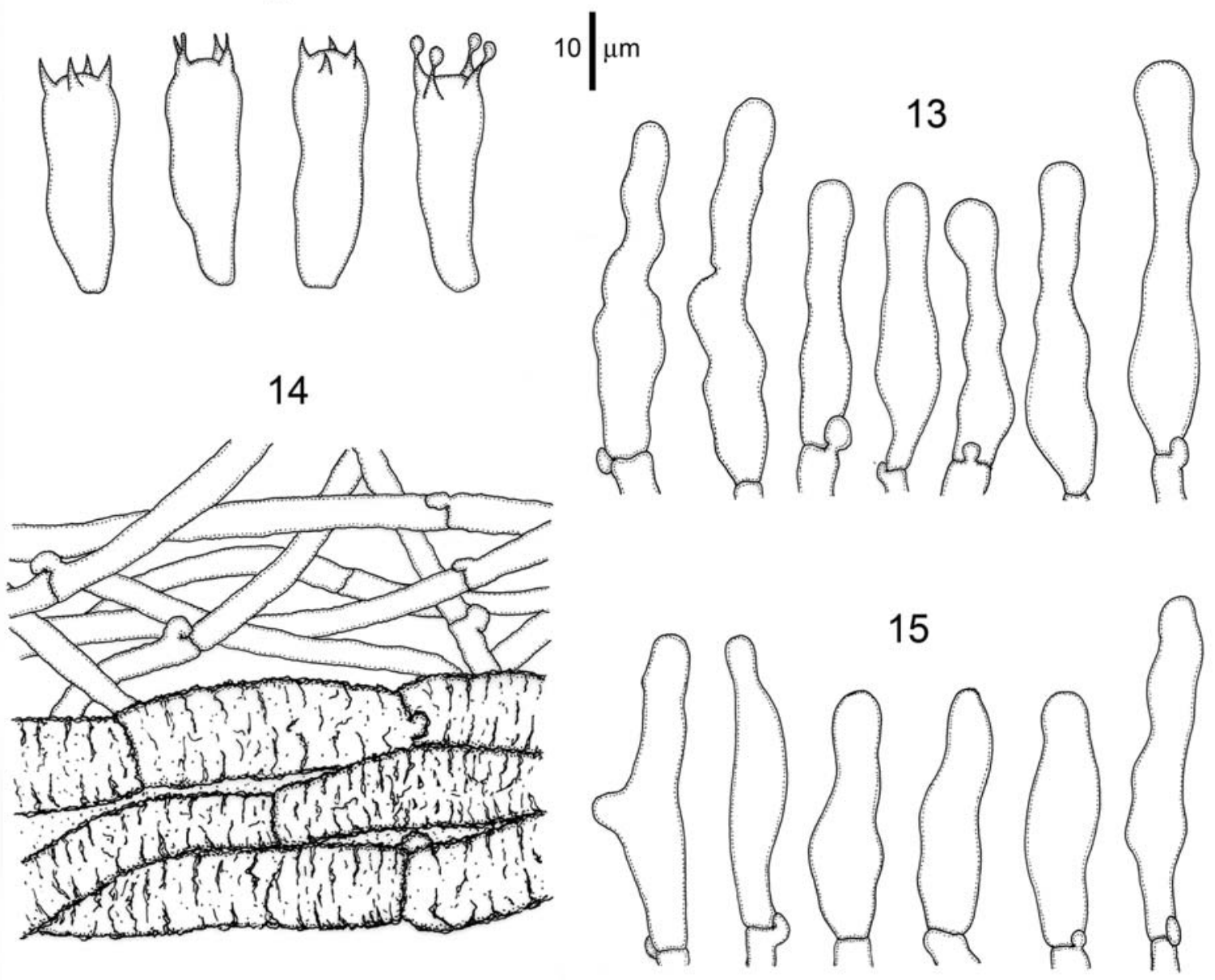

Figures 9-15. Hypholoma ericaeum. 9. Basidiomata. 10. Basidiospores. 11. Pleurocystidia. 12. Basidia. 13. Cheilocystidia. 14. Pileipellis and hypodermium. 15. Caulocystidia. 
gelatinized hyphae, 3-7 $\mu$ m diam., with smooth and thin walls. Hypodermium formed by short or filamentous hyphae, 8-13 $\mu \mathrm{m}$ diam., with walls strongly incrusted by yellowish pigments. Context formed by inflated, hyaline hyphae, smooth and thin-walled, 7-13 $\mu$ m diam. Hymenophoral trama regular, formed by cylindrical hyphae, smooth and thin-walled, 6-13 $\mu \mathrm{m}$ in diam. Stipitipellis composed of parallel, non-gelatinized hyphae, walls smooth to slightly incrusted, thin-walled, 3-10 $\mu \mathrm{m}$ in diam. Caulocystidia (21-)25-39(-45) $\times$ (5-)8-12 $\mu \mathrm{m}$; as leptocystidia, subcylindrical, lageniform to subcapitate, similar to cheilocystidia; smooth and thinwalled, hyaline, without contents; present on stipe apex. Clamp connections present in most septa.

Habitat: growing gregariously on wet soils, some sandy soils, among grasses and mosses, in meadows.

Distribution: Europe (Noordeloos 1999; Watling \& Gregory 1987), North America (Smith 1951), South America (Delgado \& Urdaneta 2002).

Material examined: BRAZIL. Rio Grande do Sul: Bagé, Campus Rural URCAMP, 30/V/2004, L.F.P. Lima 010 (ICN 139.033); Caçapava do Sul, Guaritas, 30/IV/2005, Cortez 031/05 (ICN 139.112); Cambará do Sul, Parque Nacional da Serra Geral, 19/XII/2004, G. Coelho s.n. (ICN 139.036), Parque Nacional dos Aparados da Serra, 3/IV/2005, leg. M.A. Reck, Cortez 009/05 (ICN 139.096); Santa Maria, Camobi, 10/VI/2003, Cortez 016/03 (SMDB 9.613); São Francisco de Paula, CPCN Pró-Mata (PUCRS), 10/VI/2005, Cortez 069/05 (ICN 139.147), Floresta Nacional IBAMA, 14/V/2005, Cortez 040/05 (ICN 139.118), Loteamento Colinas, 6/II/1987, M. Amaral (HCB 13.639), undetermined locality, 18/XI/2004, E. Musskopf \& L.F.P. Lima (ICN 139.035); São Leopoldo, Rick 15.235 (PACA 9.373 - as Stropharia squamosa Fr.); Viamão, Parque Estadual de Itapuã, Lagoa Negra, 22/V/2004, Cortez 021/04 (ICN 139.008), Cortez 022/04 (ICN 139.009) and Cortez 023/04 (ICN 139010), 17/VII/2004, Cortez 047/04 (ICN 139.023).

Discussion: In Brazil, H. ericaeum was only reported in the states of Paraná (de Meijer 2001) and Rio Grande do Sul, where it was cited by Rick (1961) as Psilocybe ericaea Pers., and as P. tortipes Speg. (Rick 1939), and also by Singer (1953) as Nematoloma subumbonatescens (Murrill) Singer, whose basonym (Stropharia subumbonatescens Murrill) was considered by Smith (1951) a synonym of Nematoloma ericaeum (Pers.: Fr) A.H. Sm. Rick's materials of $P$. ericaea and $P$. tortipes were not received from herbarium PACA, but the specimens labeled as
Stropharia squamosa Fr. (Rick 15.235) are in fact H. ericaeum.

On proposing the new combination, in fact Kühner (1936) mistakenly described specimens of $H$. ericaeoides P.D. Orton, a very similar species, with shorter basidiospores ( $9-12 \mu \mathrm{m}$ long) and yellowish gills (Orton 1960; Noordeloos 1999). Another similar and frequently confounded species is $H$. subericaeum (Fr.) Kühner, which has basidiospores 7-9 $\mu \mathrm{m}$ long (Noordeloos 1999).

This species has been reported as common in Europe (Noordeloos 1999), but Smith (1951) considered it rare in North America. We also considered it a common agaric in Rio Grande do Sul, fruiting mainly in autumn.

3. Hypholoma subviride (Berk. \& M.A. Curtis) Dennis, Kew Bull. 15: 134, 1961. Fig. 16-23, 26.

Agaricus subviridis Berk. \& M.A. Curtis, J. Linn. Soc. 10: 292, 1868.

Psilocybe subviridis (Berk. \& M.A. Curtis) Sacc., Syll. Fung. 5: 1051, 1887.

Nematoloma subviride (Berk. \& M.A. Curtis) A.H. Sm., Mycologia 43: 519, 1951.

H. fasciculare var. subviride (Berk. \& M.A. Curtis)

Krieglst., Beitr. Kennt. Pilze Mitteleur. 2: 144, 1986.

Pileus 4-35 (-45) mm diam., first conical, convex, then finally flattened, with or without an umbo; color yellow (5Y 7/6-7/8) in younger stages then sulphur yellow; surface smooth, subviscid to dry; margin regular, little or not striate, rarely bearing velar remnants; context thin, greenish. Lamellae adnate, close; color firstly sulphur yellow, then dark reddish brown (5YR 2.5/2-3/2) with the maturity of basidiospores; margin regular, with the same color as the sides. Stipe (7-)14-66×1-4 mm, central, cylindrical, with little expanded base; color sulphur yellow; surface dry to little humid, longitudinally striate; basal mycelium whitish, poorly developed, rhizomorphs absent. Veil arachnoid, very ephemeral, observed in earlier stages and absent in adult basidiomata. Spore print dark vinaceous brown.Basidiospores (5.5-)6-8(-9)× 3.5-5 $\mu \mathrm{m},\left(Q=1.50-2.00, Q_{m}=1.71, n=148\right)$, ellipsoid to slightly ovoid both in side and frontal view; smooth and thick-walled, with truncate germ-pore; color yellowish brown in $\mathrm{KOH}$. Basidia 15-23×4.5-7 $\mu \mathrm{m}$, clavate, bearing four sterigmata. Pleurocystidia (19-)25-38(-47)×(5.5-) 8-12 $\mu \mathrm{m}$, as chrysocystidia, fusoid to clavate, with mucronate apex; smooth and thin-walled, with yellowish amorphous content, numerous in the gill sides. Cheilocystidia 

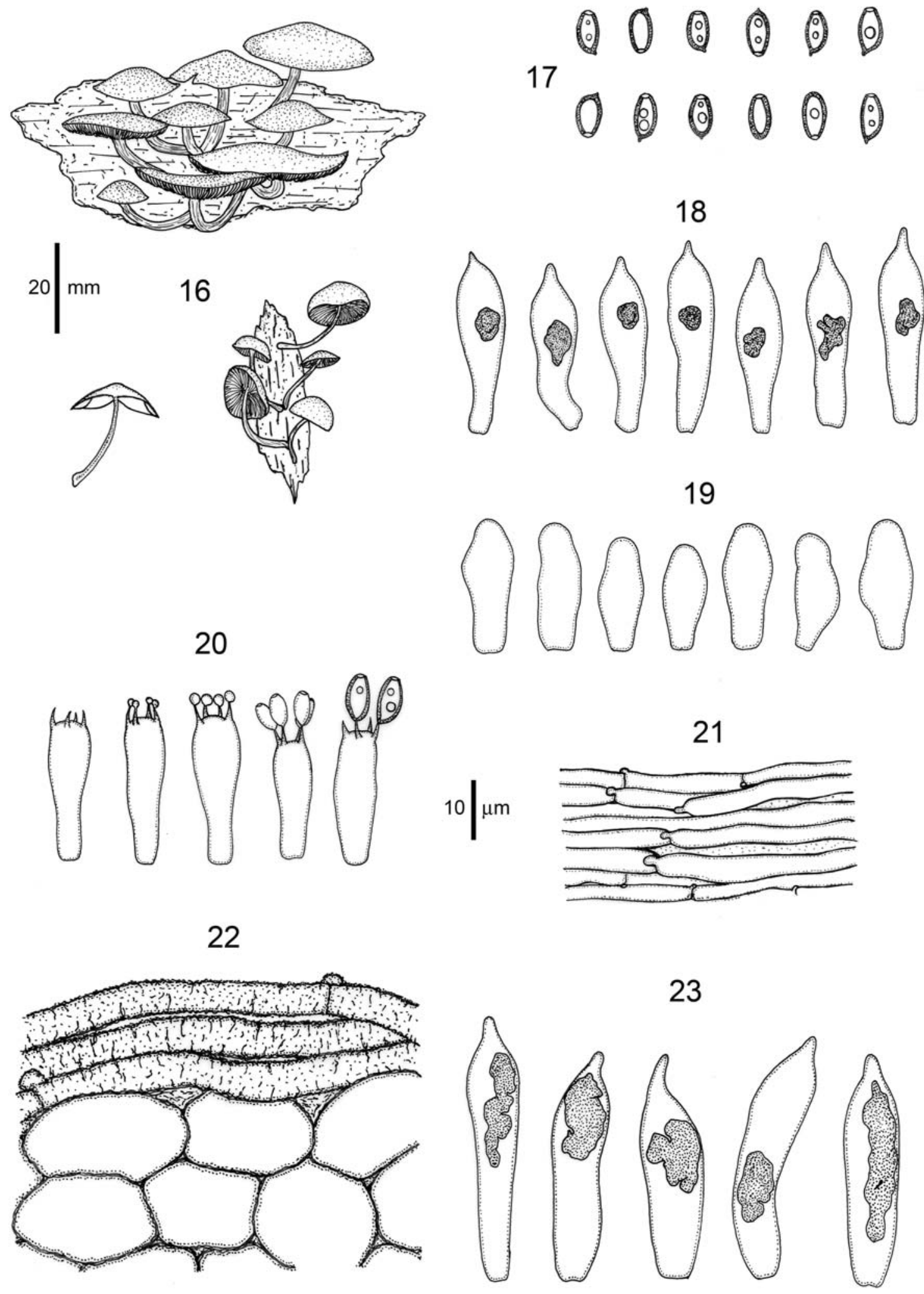

Figures 16-23. Hypholoma subviride. 16. Basidiomata. 17. Basidiospores. 18. Pleurocystidia. 19. Cheilocystidia. 20. Basidia. 21. Hymenophoral trama. 22. Pileipellis and hypodermium. 23. Caulocystidia. 
(13-)18-22(-26)×6-8 $\mu \mathrm{m}$, as leptocystidia, utriform to cylindrical, with rounded apex; hyaline, lacking yellowish contents; hard to find in dry specimens. Pileipellis composed by parallel, poorly gelatinized hyphae, 5-9 $\mu \mathrm{m}$ diam., with walls slightly thickened and incrusted by yellowish pigments. Hypodermium cellular, formed by subglobose hyphae, 15-29 $\mu \mathrm{m}$ diam. hyphae, with walls thickened and incrusted by yellowish pigments. Context composed of interwoven, hyaline hyphae, smooth and thin-walled, 5-10 $\mu \mathrm{m}$ diam. Hymenophoral trama regular, formed by hyphae with slightly incrusted walls, yellowish in $\mathrm{KOH}, 3-7(-10) \mu \mathrm{m}$ diam. Stipitipellis composed of parallel hyphae, smooth and thin-walled, 3-7 $\mu \mathrm{m}$ diam. Caulocystidia $30-44(-60) \times 8-10 \mu \mathrm{m}$, as chrysocystidia, similar to the pleurocystidia; scattered in the stipe apex, hard to find in dry specimens. Clamp connections present in most septa.

Habitat: cespitose to fasciculate on wood of Eucalyptus spp., Araucaria angustifolia (Bertol.) O. Ktze., Prunus sellowii Hoehne, among others.

Distribution: Widespread in tropical and subtropical areas of Africa (Pegler 1977; Reid \& Eicker 1999), Asia (Pegler 1986), Central America (Pegler 1983), Europe (Krieglsteiner \& Enderle 1986), North America (Smith 1951), and South America (Dennis 1970; Pulido 1983).

Material examined: BRAZIL. Rio Grande do Sul: Canela, Parque Estadual do Caracol, 6/V/.2000, M. Vergara (HASU 8.747); Esmeralda, Estação Ecológica de Aracuri, 24/XI/2004, Cortez 051/04 (ICN 139.026); Nova Petrópolis, VII/1996, R.T. Guerrero \& R.M. Silveira (ICN 102.555), Mato do Lenz, 18/VI/2004, Cortez 031/04 (ICN 139.013), Parque do Imigrante, 18/VI/2004, Cortez 032/04 (ICN 139.014); Porto Alegre, Belém Novo, VI/1992, M.S. Hamme (ICN 80.992); Santa Maria, Campus UFSM, 29/VIII/2000, Cortez 041/00 (SMDB 9.226), Jardim Botânico UFSM, 12/VIII/2002, Cortez 047/02 (SMDB 9.585), Morro do Elefante, 9/V/2001, Cortez 024/01 (SMDB 9.244), 21/VII/2001, Wartchow 007 (SMDB 9.190); Salvador do Sul, 27/IV/1943, Rick 13.330 (PACA 8.678), 1943, Rick 20.232 (PACA 8.681); São Francisco de Paula, CPCN Pró-Mata (PUCRS), 10/VI/2005, Cortez 070/05 (ICN 139.148) and Cortez 075/05 (ICN 139.153), Floresta Nacional do IBAMA, 21/V/1980, A. Batista (ICN 6.885), 23/VII/1980, A. Batista (ICN 6.888), 11/IX/1980, A. Batista (ICN 6.889), 23/IV/1996, R.T. Guerrero \& R.M.B. Silveira (ICN 102.571), 7/VI/1996, Sulzbacher et al. (HCB 16.787), 14/V/2005, Cortez 042/05 (ICN 139.120),
11/IX/2005, Cortez 084/05 (ICN 139.162), Loteamento Colinas, 21/V/1987, Marlene (HCB 13.640), Veraneio Hampel, 4/VI/2004, Cortez 029/04 (ICN 139.012); São Leopoldo, 1929, Rick 13.340 (PACA 8.680); Sinimbu, Cava Funda, 16/VII/2001, M. Sulzbacher 25 (HCB 17.516); Torres, Roça da Estância, 8/VI/1987, M.S.K. Alves (HCB 13.305),
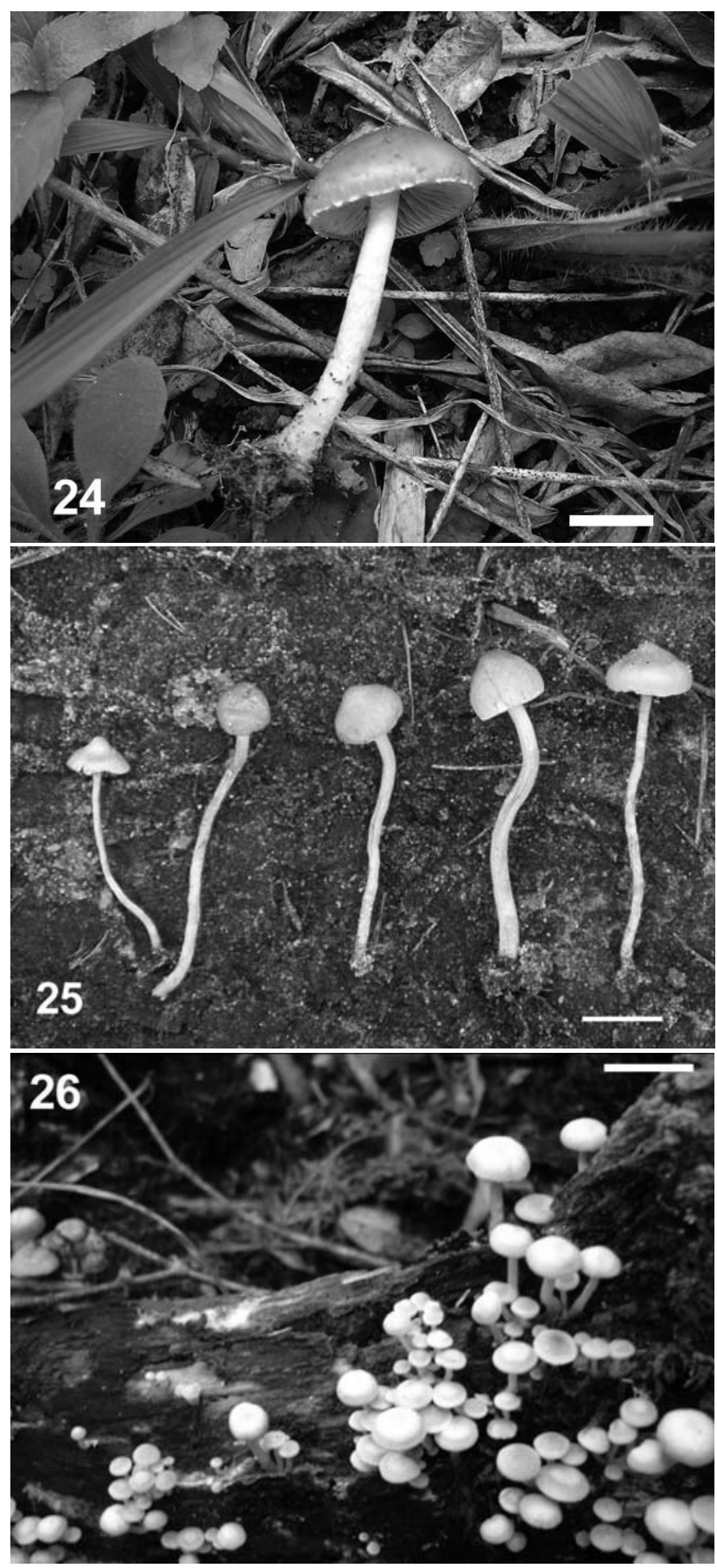

Figures 24-26. Basidiomata of Hypholoma aurantiacum (24), Hypholoma ericaeum (25) and Hypholoma subviride (26). Scale: $20 \mathrm{~mm}$. 
7/VIII/1987, M.S.K. Alves (HCB 14.844).

Additional material examined: BRAZIL. Santa Catarina: Florianópolis: Morro do Baú, 25/VII/2005, (FLOR). São Paulo: Campos do Jordão, Parque Estadual de Campos do Jordão, 8/VII/1985, M. Capelari 391 (SP 193.938); Cananéia, Parque Estadual da Ilha do Cardoso, Ilha do Cardoso, 17/XI/1982, Guzmán et al. (SP 177.888); Santo André, Reserva Biológica do Alto da Serra de Paranapiaçaba, 8/V/1989, M. Capelari 2.026 (SP 250.493); São Paulo, leg. Hoehne, Rick 13.333 (PACA 8.679).

Additional specimens of Hypholoma fasciculare: MEXICO. San Pedro de Atlapulco: La Marquesa, VIII/1962, Guzmán (SP 84.069). MOLDAVIA. District Suceava: 6/IX/1962, T. Chifu (SP 211.974).

Discussion: In spite of being a common mushroom, H. subviride was only recently reported from Rio Grande do Sul by Cortez \& Coelho (2004) and Sobestiansky (2005). The specimens recorded by Rick $(1939 ; 1961)$ as $H$. fasciculare are $H$. subviride in the present concept, a conclusion based on comparison between Rick's collections and northern specimens of $H$. fasciculare (see additional specimens examined). There are doubts about the true specific differences between $H$. fasciculare and $H$. subviride. We followed Smith (1951), Dennis (1970) and Pegler (1977; $1983 ; 1986)$, who used the size of the basidiomes to separate both taxa: pileus up to $30 \mathrm{~mm}$ in $H$. subviride versus pileus larger than $30 \mathrm{~mm}$ in $H$. fasciculare. Another feature we have noted is a more developed veil in $H$. fasciculare, frequently forming a blackish annular zone on the stipe apex and also on the pileus margin; this condition, however, is never found in $H$. subviride. Molecular analysis performed by Moncalvo et al. (2002) also suggested close relationships between these species. Hypholoma subviride is also known in the Brazilian states of Amapá (Sotão et al. 1991), Paraná (de Meijer 2001), São Paulo (Bononi et al. 1984; Pegler 1997) and probably the first record for Santa Catarina.

Synonyms, excluded or doubtful species

The names of the following taxa (including their authorities) are presented exactly as they were published by Rick in his numerous papers (see Bibliographic References). Several species reported by Rick (1961) do not have preserved specimens; others, however, never were published or reported by Rick, but were located at the herbarium PACA and therefore they are included here.
Hypholoma appendiculatum Bull. - The mushroom reported by Rick $(1939,1961)$ is probably a Pholiota sp., due the fasciculate habit, absence of rhizomorphs, ellipsoid basidiospores (7-7.5×4-4.5 $\mu \mathrm{m})$ with a wide germ pore, presence of chrysocystidia, and undifferentiated hypodermium. Material examined: BRAZIL. Rio Grande do Sul: São Leopoldo, 1930, Rick 13.339 (PACA 8.674).

H. candolleanum Fr. - The studied material corresponds to Psathyrella candolleana (Fr.) Maire, a common lignicolous to sublignicolous species in the state. Material examined: BRAZIL. Rio Grande do Sul: São Leopoldo, 1936, Rick 13.338 (PACA 8.677).

H. cascum Fr. - Cited by Rick (1961), but without specimens indicated, probably no material preserved in the herbarium PACA. If correctly identified, the species refers to Psathyrella casca (Fr.) Konrad \& Maubl., however we consider it a doubtful record.

H. dispersum Fr. - No material preserved in the herbarium PACA and also specimens not cited in Rick (1961) where this species was reported. If Rick identified his specimens correctly, this would represent a fourth species of the genus in Rio Grande do Sul, however we consider it a doubtful species at present.

H. fasciculare Huds.: Fr. - Reports given by Rick (1939, 1961) under this name are H. subviride, see discussion above.

H. hydrophilum Bull. - Probably no material preserved in the herbarium PACA and specimens not indicated in Rick (1961). If correctly identified, the species refers to a member of the genus Psathyrella, currently known as $P$. hydrophila (Bull.) Maire.

H. intonsum Passer. - This is a doubtful species or a possible synonym of some known species in its original sense because there is no modern information about this name. The specimen reported by Rick (1961) is in fact a Stropharia sp. due to the presence of abundant acanthocytes in the rhizomorphs; his description (Rick 1907, 1939, 1961) is identical (if not a transcription) of those presented by Saccardo (1887). Material examined: BRAZIL. Rio Grande do Sul: Esteio, 1939, Rick 13.332 (PACA 8.692).

H. lanaripes Cooke - Probably no material preserved and specimens were not indicated in the report by Rick (1961). This could to represent $H$. lanaripes (Cooke) Fr., but without preserved material, we consider it a doubtful record.

H. leucotephrum Berk. - The mushrooms belong to Psathyrella, possibly P. leucotephra (Berk. \& Br.) P.D. Orton or P. candolleana, but the badly preserved specimens did not allowed a complete study. Material 
examined: BRAZIL. Rio Grande do Sul: São Leopoldo, 10.1929, leg. Steffen, Rick 13.336 (PACA 8.684).

H. piluliforme Bull. - Probably another Psathyrella sp., however it was not possible to confirm it as P. piluliformis (Bull.: Fr.) P.D. Orton due to the poor condition of the basidiomata. Material examined: BRAZIL. Rio Grande do Sul: Lajeado, 15.07.1919, Rick (SP 33.909).

H. solitarium Rick - The holotype described by Rick (1961) did not present chrysocystidia, and the cheilocystidia were not observed, but the basidiospores are rhomboid in frontal view $(9-10 \sim \mathrm{m})$. These data suggest it to be a member of Psilocybe sect. Cordisporae Guzmán; however it was not possible to identify the material at specific level because it is completely mouldy. Material examined: BRAZIL. Rio Grande do Sul: Esteio, 1930, Rick 13.341 (PACA 8.685).

Naematoloma sp. - Hebeloma miserum Rick was described by Rick (1930), however Singer (1953) after the study of the holotype determined it as Naematoloma sp. The specimens indicated by Rick and Singer were not received from the herbarium PACA.

Psilocybe ericaea Pers. - Material under this name was not received from the herbarium PACA, but Singer (1953) reported these specimens as Naematoloma subumbonatescens Murrill, a synonym of $H$. ericaeum - see discussion under this species.

P. tortipes Speg. - Singer (1953) studied collections under this name and concluded it to be the same as $N$. subumbonatescens (= H. ericaeum).

P. uda Pers. - Psilocybe uda is currently known as H. udum (Pers.: Fr.) Kühner; however, the authentic specimens reported by Rick $(1939,1961)$ were not received from the herbarium PACA. Singer (1953) collected specimens in Rio Grande do Sul under this name, which were subsequently described as a new species (Psilocybe paupera Singer) by Singer (1955). Singer (1953) considered Ricks' determination of $P$. $u d a$ a misidentification.

Stropharia squamosa Fr. - The material collected but not published by Rick under this name is in fact $H$. ericaeum (see discussion under this species). Material examined: BRAZIL. Rio Grande do Sul: São Leopoldo, Rick 15.235 (PACA 9.373).

S. thrausta Kalchbr. - Cited by Rick (1907), it is considered a true $H$. aurantiacum (see discussion under this species). Psilocybe squamosa var. thrausta (Schulzer ex Kalchbr.) Guzmán, reported in the checklist of Psilocybe from Brazil by Guzmán \& Cortez (2004) based on Rick's report, should not be considered in Psilocybe since they represent H. aurantiacum.

\section{Acknowledgements}

The authors thank the curators of the mentioned herbaria for specimen loans, especially the herbarium PACA for allowing us to study the Fungi Rickiani collection. We thank all mycologists for sending literature and information. The CNPq (Brazil) is acknowledged for financial support given to the first author.

\section{References}

Badalyan, S.M. 2003. Edible and medicinal higher basidiomycete mushrooms as a source of natural antioxidants. International Journal of Medicinal Mushrooms 5: 153-162.

Badalyan, S.M.; Innocenti, G. \& Garibyan, N.G. 2002. Antagonistic activity of xylotrophic mushrooms against pathogenic fungi of cereals in dual culture. Phytopathologia Mediterranea 41: 200-225.

Badalyan, S.M.; Rapior, S.; Le Quang, J.; Doko, L.; Jacob, M.; Andary, C. \& Serrano, J.-J. 1995. Investigation of fungal metabolites and acute toxicity studies from fruitbodies of Hypholoma species (Strophariaceae). Cryptogamie, Mycologie 16: 79-84.

Badalyan, S.M. \& Serrano, J.-J. 1999. Hypoglycemic activity of poisonous mushroom Hypholoma fasciculare (Fr.) Kumm. International Journal of Medicinal Mushrooms 1: 245-250.

Baletto, C. 1989. Problemi di nomenclatura - XV. Micologia Italiana 18: 33-37.

Bon, M. \& Roux, P. 2003. Clé analytique de la famille Strophariaceae Singer \& A.H. Smith. Documents Mycologiques 129: 3-56.

Bononi, V.L.; Mucci, E.S.F.; Yokomizo, N.K.S. \& Guzmán, G. 1984. Agaricales (Basidiomycetes) do Parque Estadual de Campos do Jordão, SP, Brasil. Rickia 11: 85-89.

CABI. 2005. Index Fungorum: Authors of Fungal Names. Available at: http://www. indexfungorum.org/authors. (Accessed: 8.12.2005).

Chapman, B.; Xiao, G. \& Myers, S. 2004. Early results from field trails using Hypholoma fasciculare to reduce Armillaria ostoyae root disease. Canadian Journal of Botany 82: 962-969.

Cortez, V.G. \& Coelho, G. 2004. The Stropharioideae (Strophariaceae, Agaricales) from Santa Maria, Rio Grande do Sul, Brazil. Mycotaxon 89: 355-378.

de Meijer, A.A.R. 2001. Mycological work in the Brazilian State of Paraná. Nova Hedwigia 72: 105-159. 
Delgado, A.E. \& Urdaneta, L.M. 2002. Hongos Basidiomycota, orden Agaricales, en cinco municipios del estado Zulia, Venezuela. Revista de la Facultad de Agronomía de la Universidad del Zulia (LUZ) 19: 56-70.

Dennis, R.W.G. 1970. Fungus flora of Venezuela and adjacent countries. Kew Bulletin Additional Series 3: 1-515.

Dennis, R.W.G.; Wakefield, E.M. \& Bisby, G.R. 1954. The nomenclature of Armillaria, Hypholoma and Entoloma. Transactions of the British Mycological Society 37: 33-37.

Farr, D.F. 1980. The acanthocyte, a unique cell type in Stropharia (Agaricales). Mycotaxon 11: 241-249.

Farr, D.F. 1985. Scanning electron microscopic observations of basidiospores in Pholiota and related genera. Canadian Journal of Botany 63: 603-610.

Farr, E.R. \& Farr, D.F. 1981. Proposals to conserve or reject Hypholoma (Fr.) Kummer against Nematoloma Karsten or Psathyrella (Fr.) Quél. (Agaricales). Taxon 30: 329-334.

Grgurinovic, C.A. \& Simpson, J.A. 2001. Conservation status of the known Agaricales, Boletales, Cantharellales, Lycoperdales, Phallales and Russulales of South Australia. Fungal Diversity 8: 97-127.

Guzmán, G. 1975. New and interesting Agaricales from Mexico. Beiheft zur Nova Hedwigia 51: 99-118.

Guzmán, G. 1980. Three new sections in the genus Naematoloma and a description of a new tropical species. Mycotaxon 12: 235-240.

Guzmán, G. 1983. The genus Psilocybe. Beiheft zur Nova Hedwigia 74: 1-439.

Guzmán, G. 1999. New combinations in Hypholoma and information on the distribution and properties of the species. Documents Mycologiques 114: 65-66.

Guzmán, G. \& Cortez, V.G. 2004. The neurotropic Psilocybe (Fr.) P. Kumm. (Agaricales, Strophariaceae) in Brazil: a revision of the known species, the first record of $P$. wrightii, and the synonymy of $P$. caeruleoannulata. International Journal of Medicinal Mushrooms 6: 383-388.

Hawksworth, D.L. 2001. The naming of Fungi. Pp. 171-192. In: D.J. McLaughlin; E.G. McLaughlin \& P.A. Lemke (eds.). The Mycota VII: Systematics and Evolution, Part B. Berlin, Springer Verlag.

Hawksworth, D.L. 2005. Reflections on changing names and related nomenclatural issues in edible and medicinal mushrooms. International Journal of Medicinal Mushrooms 7: 29-38.

Hawksworth, D.L.; Kirk, P.M.; Sutton, B.C. \& Pegler, D.N. 1995. Ainsworth \& Bisby's Dictionary of the Fungi. $8^{\text {th }}$ ed. Surrey: International Mycological Institute/CABI Publishing.

Hofrichter, M. \& Fritsche, W. 1997. Depolymerization of lowrank coal by extracellular fungal enzyme fungi. II. The ligninolytic enzymes of coal-humic-acid-depolimerizing fungus Naematoloma frowardii. Applied Microbiology and Biotechnology 47: 419-425.

Holmgren, P.K. \& Holmgren, N.H. 1998-2005. Index Herbariorum. Available at: http://sciweb.nybg.org/ science2/IndexHerbariorum.asp. (Accessed in: 8.12.2005).
Korf, R. P. 1986. Report of the Committee for Fungi and Lichens. Taxon 35: 552-556.

Krieglsteiner, G.J. \& Enderle, M. 1986. Über neue, seltene, kritische makromyzeten in der Bundesrepublik Deutschland (Mitteleuropa) VII. Beiträge zur Kenntnis der Pilze Mitteleuropas 2: 125-162.

Kühner, R. 1936. Observations sur le genre Hypholoma. Bulletin de la Société Mycologique de France 52: 9-30.

Kühner, R. 1980. Les Hymenomycétes Agaricoides: Étude Générale et Classification. Lyon, Société Mycologique de Lyon.

Largent, D.L. 1977. How to Identify Mushrooms to Genus. I. Macroscopic features. Eureka, Eureka Publishing.

Largent, D.L.; Johnson, D. \& Watling, R. 1986. How to Identify Mushrooms to Genus. III. Microscopic features. Eureka, Eureka Publishing.

Moncalvo, J.-M.; Vilgalys, R.; Redhead, S.A.; Johnson, J.E.; James, T.Y.; Aime, M. C.; Hoffstetter, V.; Verduin, S.J.W.; Larsson, E.; Baroni, T.J.; Thorn, R.G.; Jacobsson, S.; Clémençon, H. \& Miller Jr., O.K. 2002. One hundred and seventeen clades of euagarics. Molecular Phylogenetics and Evolution 23: 357-400.

Munsell. 1994. Munsell Soil Color Charts. New Windsor, Macbeth.

Murrill, W.A. 1922. Dark-spored Agarics - II. Gomphidius and Stropharia. Mycologia 4: 121-142.

Norvell, L.L. \& Redhead, S.A. 2000. Stropharia albivelata and its basionym Pholiota albivelata. Mycotaxon 76: 315-320.

Noordeloos, M.E. 1995. Notulae ad Floram Agaricinam Neerlandicam XXIII - Psilocybe and Pholiota. Persoonia 16: 127-129.

Noordeloos, M.E. 1999. Strophariacaeae. Pp. 27-107. In: C. Bas; T.H. Kuyper; M.E. Noordeloos \& E. Vellinga (eds.). Flora Agaricina Neerlandica. v.4. Rotterdam, A. A. Balkema.

Orton, P.D. 1960. New checklist of British agarics and boleti. Part III. Notes on genera and species in the list. Transactions of the British Mycological Society 43: 159-439.

Pegler, D.N. 1977. A preliminary agaric flora of East Africa. Kew Bulletin Additional Series 6: 1-615.

Pegler, D.N. 1983. Agaric flora of the Lesser Antilles. Kew Bulletin Additional Series 9: 1-668.

Pegler, D.N. 1986. Agaric flora of Sri Lanka. Kew Bulletin Additional Series 12: 1-519.

Pegler, D.N. 1996. Agarics described from Cape Province, South Africa. Kew Bulletin 51: 787-797.

Pegler, D.N. 1997. The Agarics of São Paulo, Brazil. London, HMSO, Royal Botanic Gardens, Kew.

Pegler, D.N. \& Legon, N.W. 1998. Profiles of Fungi. 97. Stropharia aurantiaca (Cooke) Imai. Mycologist 12: $1-180$.

Pulido, M.M.O. 1983. Estudios en Agaricales Colombianos - Hongos de Colombia IX. Bogotá, Instituto de Ciencias Naturales/Museo de Historia Natural.

Raithelhuber, J. 1985. Spec. nov., comb. nov., nom. nov. et stat. nov. Metrodiana 11: 50-51. 
Reid, D.A. \& Eicker, A. 1999. South African Fungi 10: new species, new records and some new observations. Mycotaxon 73: 169-197.

Rick, J. 1907. Contributio ad monographiam Agaricacearum et Polyporacearum Brasiliensium. Brotéria, Série Botânica 6: 65-92.

Rick, J. 1930. Contributio ad monographiam Agaricacearum et Polyporacearum Brasiliensium. IV. Brotéria, Série Botânica 24: 27-114.

Rick, J. 1939. Agarici Riograndensis III. Lilloa 4: 75-104.

Rick, J. 1961. Basidiomycetes Eubasidii in Rio Grande do Sul - Brasilia. 5. Agaricaceae. Iheringia, Série Botânica 8: $296-450$.

Saccardo, P.A. 1887. Sylloge Hymenomycetum. V.I: Agaricinea. Patavii.

Segedin, B.P. \& Pennycook, S.R. 2001. A nomenclatural checklist of agarics, boletes, and related secotioid and gasteromycetous fungi recorded from New Zealand. New Zealand Journal of Botany 39: 285-348.

Singer, R. 1950. Type studies on Basidiomycetes. Lilloa 23: 147-246.

Singer, R. 1953. Type studies on Basidiomycetes VI. Lilloa 26: $57-159$.

Singer, R. 1955. Type studies on Basidiomycetes VII. Sydowia 9: 367-431.

Singer, R. 1969. Mycoflora Australis. Beiheft zur Nova Hedwigia 29: 1-405.

Singer, R. 1973. Diagnosis Fungorum Novorum Agaricalium III. Beiheft Sydowia 7: 1-106.

Singer, R. 1986. The Agaricales in Modern Taxonomy. $4^{\text {th }}$ ed. Koenigstein, Koeltz Scientific Books.
Singer, R. \& Smith, A.H. 1946. Proposals concerning the nomenclature of the gill fungi including a list of proposed lectotypes and genera conservanda. Mycologia 38: 240-299.

Smith, A.H. 1951. The North-American species of Naematoloma. Mycologia 43: 467-521.

Smith, A.H. 1979. Generic concepts within the Strophariaceae of the Agaricales. Taxon 28: 19-21.

Sobestiansky, G. 2005. Contribution to a macromycete survey of the states of Rio Grande do Sul and Santa Catarina in Brazil. Brazilian Archives of Biology and Technology 48: 437-457.

Sotão, H.M.P.; Bononi, V.L.R. \& Figueiredo, T.S. 1991. Basidiomycetes de manguezais da Ilha de Maracá, Amapá, Brasil. Boletim do Museu Paraense Emílio Goeldi, Série Botânica 7: 109-114.

Spegazzini, C. 1889. Fungi Puiggariani. Pugillus I. Boletín de la Academia Nacional de Ciencias de Córdoba 11: 381-622.

Steffen, K.T.; Hofrichter, M. \& Hatakka, A. 2000. Mineralisation of ${ }^{14} \mathrm{C}$-labelled synthetic lignin and ligninolytic enzyme activities of litter-decomposing basidiomycetous fungi. Applied Microbiology and Biotechnology 54: 819-825.

Stijve, T. \& de Meijer, A.A.R. 1993. Macromycetes from the state of Paraná. 4: The psychoactive species. Arquivos de Biologia e Tecnologia 36: 313-329.

Watling, R. \& Gregory, N.M. 1987. British Fungus Flora 5: Strophariaceae \& Coprinaceae p.p. Edinburgh, HMSO, Royal Botanic Gardens, Edinburgh.

Wright, J.E. \& Albertó, E. 2002. Guía de los Hongos de La Región Pampeana. I. Hongos con Laminillas. Buenos Aires, L.O.L.A. 